\title{
Islam dan Demokrasi Pasca Orde Baru
}

\author{
Sembodo Ardi Widodo \\ Universitas Islam Negeri Sunan Kalijaga Yogyakarta
}

\begin{abstract}
This article explains the relation and contribution of state, civil society and Islam in the process of changing leadership and developing society in order to create the process of democracy in the post-failing New Order. In a historical context, the civil society and Islam, representing the majority of Indonesian people, plays an important role in determining the reformation of the social and political fields, and are directly involved in the process of changing and creating the process of democracy, compatible with the condition of political development in Indonesia. Although these three of state, civil society and religion (Islam) have some weakness, but in a historical context of Indonesia, they have become the success key in creating the process of democracy and changing leadership in the postfailing New Order.
\end{abstract}

Keywords: Islam, relation, contribution, democracy

Dasca jatuhnya rezim Soeharto, yang dipelopori oleh gerakan mahasiswa, tepatnya 21 Mei 1998, menaruh harapan besar bagi rakyat Indonesia untuk membangun iklim demokrasi di Nusantara ini. Selama \pm 32 tahun mereka berada dalam 'kungkungan' rezim otoritarian. Angin segar kebebasan mulai dirasakan oleh rakyat. Optimisme tersebut semakin kuat tatkala, $\mathrm{KH}$. Abdurrahman Wahid-biasa disebut Gus Dus - terpilih sebagai presiden RI yang terus mendengungkan demokrasi, meskipun kita sering dibingungkan dengan kebijakankebijakan yang terus berubah-ubah. Diakui atau tidak, tokoh yang berlatarbelakang dari pesantren ini telah memberikan sumbangan yang besar terhadap proses demokratisasi di Indonesia.

Meminjam tipologi yang dibangun oleh Clifford Geertz (1989) terhadap penggolongan kaum muslim menjadi santri, priyayi dan abangan atau dikenal dengan

trikonomi yang banyak memunculkan perdebatan tersebut. Maka, tak berlebihan bila dikatakan bahwa kepemimpinan Gus Dur, merupakan periode naiknya santri dalam pentas politik di tingkat nasional, atau bisa disebut dengan santrinisasi politik. Prestasi tersebut tidaklah berlangsung lama, karena tak lama kemudian Gus Dur pun lengser dari kursi kepresidenan, dan digantikan oleh Megawati Soekarno Putri, yang kebetulan waktu itu beliau menjabat sebagai wakil presiden. Beberapa ancaman separatisme juga muncul bersamaan dengan peristiwa tersebut, bahkan gerakan-gerakan pendukung Gus Dur pada ranah akar rumput pun marak di berbagai daerah, terutama di Jawa bagian Timur. Akan tetapi tak bisa dipungkiri bahwa kekuatan masyarakat akar rumput sebagai pendukung Gus Dur tersebut tak dapat menandingi kekuasaan elit politik di tingkat nasional yang merupakan pemegang kebijakan dan 
penentu arah kemana Indonesia ini akan dibawa.

Dinamika sosial politik dalam masyarakat menunjukkan perubahan yang signifikan. Rupanya transformasi sosialpolitik tersebut telah memberikan ruang bagi civil society (masyarakat madani) untuk melebarkan 'sayap'nya dan kembali bersuara dengan kritisisme, di mana selama \pm 32 tahun lamanya mereka terkungkung dalam dominasi negara yang sangat sentralistik. Tak ada secercah ruang pun untuk mengekspresikan gagasan-gagasan kritis dan brillian untuk membangun bangsa Indonesia ini, bila hal itu membahayakan eksistensi status quo. Dengan demikian, tumbangnya rezim otoriter Suharto, ibarat saluran air yang sudah lama tersumbat dan akhirnya ambrol karena tekanan air yang begitu kuat. Situasi tersebut hampir dirasakan oleh seluruh elemen masyarakat.

Dunia pers, yang semula tersumbat oleh kekuasaan dan dominasi negara juga seringkali mendapatkan ancaman 'pembredelan', telah mendapatkan tempat yang seluas-luasnya untuk transformasi informasi ke ruang publik, secara lebih bebas. Kini masyarakat semakin mudah mengakses informasi, yang juga berarti semakin meningkatkan kualitas manusia Indonesia, karena revitalisasi peran media massa untuk turut serta membangun iklim yang demokratis dapat berjalan secara optimal. Di samping itu, penegakan hukum (law enforcement) juga merupakan agenda yang sangat penting, pasca reformasi politik dan kekuasaan yang dimotori oleh mahasiswa dan masyarakat sipil tersebut.

Masih dalam konteks transisi menuju demokrasi, pada masa pemerintahan Megawati juga menemui jalan terjal yang menghambat demokratisasi di Indonesia seperti, keterpurukan ekonomi, budaya korupsi, kolusi dan nepotisme (KKN), penegakan hukum belum berjalan secara maksimal, tingkat inflasi yang tinggi, konflik horizontal yang tak kunjung padam, angka kemiskinan yang semakin meningkat, biaya pendidikan yang membumbung tinggi, bahkan sampai bencana alam yang melanda di berbagai belahan wilayah nusantara ini. Sampai sekarang korupsi merupakan penyakit bangsa yang sudah akut. Bahkan mental bangsa ini telah tercemari dengan budaya korupsi yang sangat merugikan masyarakat banyak. Munculnya kasus korupsi yang diekspos di media massa, baik ditingkat nasional-pejabat terassampai dengan kepala desa, merupakan bukti yang tak terbantahkan.

Ironisnya, nilai-nilai agama yang selalu mengedepankan keselarasan sosial (social harmony) dan sekaligus mempunyai relasi transendental dengan Sang Pencipta hanya menjadi pemanis dalam pembicaraan ataupun kampanye politik dengan janji-janji yang mampu membius masyarakat, tak mampu mereduksi moralitas yang sudah tercemari dengan budaya korupsi tersebut. Padahal demokratisasi di Indonesia ini sangat tergantung pada masyarakat sipil untuk transformasi sosial.

Memang kompleksitas persoalan tersebut merupakan bagian dari warisan rezim Soeharto, sebagaimana dikatakan oleh Georg Sorensen (1993), pemerintah otoriter selain memang sudah meninggalkan kantornya, namun mereka di sisi lain juga telah meninggalkan warisan berupa masalah-masalah ekonomi akut untuk ditangani oleh pemerintah demokratis yang baru (Sorensen, 2003:96). Ini adalah PR (Pekerjaan Rumah) yang harus diselesaikan oleh pemerintah. Pertanyaannya kemudian, harus dimulai dari mana untuk membangun bangsa Indonesia yang sedang terpuruk dengan persoalan yang multikompleks? 
Islam dan Demokrasi Pasca Orde Baru; Sembodo Ardi Widodo

Haruskan kita berpangku tangan dan mempercayakan perubahan kepada beberapa pilar seperti; civil society, political society dan state aparatus (Stepan, 1996:1314) ataukah harus ada usaha yang sinergis antara masyarakat dan negara yang merupakan elemen penting dalam mewujudkan konsolidasi demokrasi dan elite sebagai kelompok yang berperan penting dalam perubahan (Sztompka, 2005:309). Oleh karena itu, tulisan ini berusaha menjelaskan relasi negara dan masyarakat sipil serta Islam dalam hubungannya mewujudkan iklim demokrasi di Indonesia, pasca jatuhnya rezim otoriter Suharto bertepatan pada 21 Mei 1998.

\section{Perubahan Sistem Politik}

Perubahan sistem perpolitikan yang ada di Indonesia, dari sentralistik ke desentralistik, telah mendorong munculnya partai politik-partai politik baru. Partai-partai yang berasaskan Islam juga naik ke pentas politik nasional seperti PAN, PPP, PKNU, PNU dan lain sebagainya. Di samping perubahan sistem perpolitikan tersebut sebagai paluang untuk menciptakan perubahan, juga dapat dimaknai sebagai tantangan, bagaimana kemudian partaipartai Islam tersebut mampu mewarnai dan sekaligus memberi kontribusi penting terhadap bangunan demokrasi di Indonesia.

Antony Giddens (1995:18-22) dalam bukunya yang berjudul, The Constitution of Society; The Outline of The Theory of Structuration, memberikan ulasan yang sangat rinci tentang 'structure' dan 'agency'. 'Structure' diartikan sebagai rules dan resources yang dipakai dalam proses produksi dan reproduksi sosial, sementara 'agency' diartikan sebagai individu yang berbuat. Keduanya mempunyai hubungan yang dialektik. Oleh karena itu, masyarakat dapat melakukan kontrol terhadap negara yang mempunyai kekuasaan yang sangat luas, inilah yang oleh Giddens disebut dengan dialektika kendali (dialectic of control). Dalam konteks, transisi menuju konsolidasi demokrasi, masyarakat dan negara mempunyai peran yang sangat sentral, meskipun kita tidak bisa menafikan peran pasar dan civil society.

Meminjam istilah Alfred Stepan (1996), bahwa masyarakat (society) bisa terbagi menjadi dua kekuatan yaitu civil society dan political society dan sebuah negara mempunyai beberapa elemen yaitu: elite politik, birokrat dan militer, untuk mengawal perubahan dari transisi menuju konsolidasi demokrasi. Karena fase ini perlu dicermati secara hati-hati. Tidak mustahil demokrasi yang mulai mekar selama ini akan layu sebelum berkembang, dan kembali pada otoritarianisme atau meminjam istilah Larry Daimond (2003:ix) menyebutnya sebagai 'otoritarian elektoral' dan tidak menutup kemungkinan malah akan melahirkan demokrasi beku (frozen democracies) atau demokrasi tidak solid. Atas dasar itulah, seluruh elemen masyarakat, buruh, pelajar, mahasiswa, dosen, NGO, partai politik, Ormas dan lain-lain- harus mempunyai komitmen normatif sebagai cita-cita bersama untuk membangun demokrasi yang terkonsolidasi (consolidated democracy). Namun selain itu, elemen di atas menjadi kering jika dianalisa tanpa memperhitungkan pembahasan dasar atas kondisi agama sebagai sebuah sistem kultural yang telah memberikan makna pada eksistensi manusia dan (yang telah memberikan) pemahaman dan dukungan emosional terhadap penderitaan manusia (Weber dan Malinowski). Tentunya hal itu juga berhubungan (dan turut memberikan pengaruh) atas lajunya proses demokrasi pasca jatuhnya rezim Orde Baru. 
UNISIA, Vol. XXX No. 65 September 2007

\section{Islam Indonesia: Kontribusi Demokrasi Pasca-Reformasi.}

Krisis politik di Indonesia yang diyakini bersumber dari dampak utama (the prominent effect) adanya krisis ekonomi semenjak pertenganan Juli 1997, merupakan awal dominasi penyebab lengsernya rezim Orde Baru. Namun anehnya saat itu, kondisi krisis ekonomi dan semakin amburadulnya tatanan demokrasi pemerintahan yang ada, masih saja MPR dan kekuatan politik yang ada memberanikan diri mancalonkan Soeharto yang sudah jelas banyak ditentang masyarakat luas (Culla,1999:159). Tak ayal jika pada akhirnya massa mahasiswa yang terus 'mengamuk' berdatangan dari berbagai kelompok antara tanggal 18-20 Mei 1998 berhasil memaksa pimpinan DPR dan stafstafnya untuk mengambil sikap atas tuntutan reformasi. Selepas kondisi itulah, yakni pasca jatuhnya rezim Orde Baru, kondisi proses demokratisasi di segala bidang mulai start untuk dijalankan demi tercapainya citacita masyarakat Indonesia yang berdaulat (Hikam, 199:27).

Membuka file itu, tentu saja mengingatkan kita pada kondisi peta Islam di Indonesia yang -saat itu dan sesudahnya- telah banyak memberikan kontribusi atas wujudnya transformasi sosial dan berlakunya sebuah proses demokratisasi yang sedang melangkah sedikit demi sedikit di Indonesia. Melihat hal itu, maka tak terbantahkan, bahwa Islam di Indonesia (Ma'arif, 1999:68), sejatinya juga telah memberikan kontribusi atas hadirnya proses iklim demokratisasi pasca jatuhnya rezim otoriter Soeharto (Mulkhan,1992-15-16). Kontribusi tersebut bisa dicermati cukup dengan dua sisi pandangan. Pertama adalah pandangan dari sisi normatif dan yang kedua adalah dari sisi praktis-historis.
Pertama, bisa terlihat dari sisi cita-cita normatif. Maksudnya adalah, bahwa Islam sebagai sebuah agama, sesungguhnya telah meletakkan beberapa dasar prinsip demokrasi dalam beberapa ajarannya seperti; shura (permusyawaratan), al-'adalah (keadilan), ijma' (konsensus), ijtihâd (kemerdekaan berpikir), tasamuh (tolerensi), al-hurrîyah (kebebasan), al-musâwah (egalitarian), ash-shidqu wal amânah (kejujuran dan tanggung jawab). Prinsip-prinsip tersebut, sebetulnya merupakan inti semangat makna demokrasi dan tentu hal itu bisa dibaca pada kitab al-Qur'an. Meskipun al-Qur'an tidak menyebut suatu bentuk dan sistem ketatanegaraan secara sharih, tatanan sistem demokrasi yang [saat itu dan sekarang] menjadi primadona bentuk demokrasi negara-negara di dunia, memiliki titik temu dan relevansi kuat untuk mengegolkan proses demokrasi di segala aspek kehidupan (Thompson, 2000:47-90). Dengan demikian, dalam Islam sebetulnya telah tertanam beberapa prinsip pokok dan tata nilai berkaitan dengan kehidupan masyarakat dan bernegara untuk menunjang lajunya proses demokrasi (Haikal, 1963:35-37).

Kedua, adalah dari sisi praktis-historis. Maksudnya adalah, bahwa selain Islam di Indonesia telah meletakkan prinsip-prinsip demokrasi, dalam prakteknya Islam juga telah membuktikan nilai-nilai tersebut. Dalam sejarah (historis) di Indonesia, para pemimpin Muslim yang mewakili mayoritas bangsa, telah memainkan peran penting dalam menentukan reformasi sosial dan politik. Bila era Orde Lama para pemimpin Muslim berperan melalui Masyumi, maka pada pasca lengsernya lengsernya Suharto, dua organisasi Islam terbesar NU dan Muhammadiyah secara proaktif terlibat langsung dalam proses perubahan kepemimpinan untuk membangun sistem demokrasi di Indonesia. 
Islam dan Demokrasi Pasca Orde Baru; Sembodo Ardi Widodo

Abdurahman Wahid (Gus Dur) dan Amin Rais yang dikenal sebagai pemimpin organisasi Islam terbesar di Indonesia, NU dan Muhammadiyah, diakui merupakan tokoh penting dan sangat vital di dalam prosesi penumbangan rezim Soeharto dan mereka cukup dikenal juga sebagai tokoh yang gandrung akan tegaknya proses dan sistem demokrasi di Indonesia. Kekuatan dan karisma yang dimiliki keduanya, tentu juga telah ditampilkan lewat masing-masing kebesaran massa organisasinya, NU dan Muhammadiyah. Turut terlibatnya mereka, sebagai pemimpin partai Islam, dalam menegakkan cita-cita demokrasi di bumi pertiwi Indonesia, merupakan bukti kongkrit bahwa cita-cita Islam sejatinya sangatlah mendukung atas berjalannya proses demokratisasi untuk menciptakan -salah satunya- masyarakat madani.

Amin Rais bersama organisasi Muhammadiyahnya yang berjumlah 28.000.000 anggota berikut dengan berjutajuta simpatisannya (Rais, 1998:266-267), sering terlihat dalam media menjadi tokoh sentral penting dalam arus perkembangan politik pasca rezim Soeharto dalam menyuarakan jargon-jargon demokrasi baik dalam ranah sosial, politik, ekonomi maupun budaya. Muhammadiyyah dan Amin Rais, sebagai organisasi masyarakat dan Ketuanya, tidak hanya bertujuan "to up-hold and to up-lift the religion of Islam so as to create the true Islamic society" saja melainkan lebih dari itu, sepak terjang Ketua PP. Muhammadiyah saat itu, sangatlah ketara ketika terlibat langsung dalam proses perubahan kepemimpinan nasional pada Mei 1998.

Pada waktu yang sama dengan momen yang berbeda, Gus Dur dengan NU-nya, juga turut diacungi jempol dalam gerakannya yang pelan tapi pasti, di dalam menumbuhkan sikap demokarasi di Indonesia. Sejak NU memutuskan kembali ke khithah 1926 pada Muktamar NU ke-27 tahun 1984 sampai peristiwa lengsernya rezim otoriter Orde Baru tahun 1998, gerakannya hanya dipusatkan pada transformasi sosialekonomi. Dalam hal ini, NU sebagai Jam'iyyah Diniyyah litima'iyyah, menegaskan keseluruh anggota dan simpatisannya untuk tidak terbuai dalam kekuasaan yang korup, nepotis, dan manipulatif (KKN). Di saat warga bangsa gila harta, jabatan, dan kursi kekuasaan, NU di era reformasi dengan tenangnya menata barisan untuk merumuskan pesan-pesan moralitas politik. Karena itulah, kasus Muktamar NU ke-29 di Cipasung, bisa dilihat sebagai contoh bahwa organisasi NU sangatlah concern terhadap demokratisasi bangsa dan negara. Dengan menanamkan sikap-sikap di atas dalam menghadapi situasi negara dan bangsa yang hampir kolep, tentunya NU telah memberikan kontribusi besar kepada bangsa dan negara dalam penegakan demokrasi di Indonesia.

Ditambah lagi dengan langkah-langkah Gus Dur dalam mengaktualisasikan demokratisasi dan penegakan HAM diberbagai persoalan bangsa, begitu pula taqrir baru para Kyai dalam membangun partai kebangkitan bangsa [PKB] yang berformat sangat inklusif, populis, moderat dan humanis, tentu saja menambah starting point bahwa Islam di Indonesia berpotensi untuk menumbuh-kembangkan sikap demokrasi. Artinya, sudah sangat klop-lah bahwa Islam di Indonesia mempunyai peran yang sangat urgen dan berpotensi menumbuhkan sikap-sikap demokrasi dilihat dari karakter normatifdan praksis-historisnya (Hefner, 2001:32). 
UNISIA, Vol. XXX No. 65 September 2007

\section{Relasi Negara dan Masyarakat di Era Transisi}

Pada tahun 1970-an terus bermunculan gerakan pro-demokrasi yang merupakan gerakan koreksi terhadap pemerintahan Soeharto, karena mereka masih percaya terhadap jalannya pemerintahan. Yang menjadi bahan koreksi adalah orang-orang Soeharto, namun pada tahun 1978 gerakan tersebut berubah haluan menjadi gerakan konfrontasi, yang dipimpin oleh mahasiswa di Bandung. Pada tahun 1978 mahasiswa meminta agar Soeharto tidak mencalonkan lagi menjadi presiden. Akhirnya mereka harus berhadapan dengan kekuatan militer sebagai cara Orde Baru untuk melakukan tindakan represif terhadap gerakan konfrontasi yang dipelopori oleh mahasiswa tersebut (Budiman \& Törnquist, 2001:xxix). Bahkan secara tiba-tiba pada tahun 1994 tiga pers nasional-Tempo, Realitas, Detik-dibredel, karena dipandang mengancam eksistensi status quo.

Berangkat dari ketidakpercayaan kepada pemerintahan presiden Soeharto munculah beberapa gerakan konfrontasi di antaranya adalah Gerakan Petani Kedung Ombo (1989), Kasus Nipah di Madura (1993), Kasus pemogokan Buruh di Medan (1994), Kasus Amungne di Irian Jaya (1996), Kasus Gerakan Anti-Kuningisasi di Solo (1997), Kasus PDI Pimpinan Megawati (1996), Kasus Pembredelan Mingguan Tempo (1994) (Budiman \& Törnquist, 2001:xxix-xlii). Nampak sekali di sini bahwa, pada era Orde Baru peran negara sangat dominatif, atau sering disebut dengan state centre. Tidak ada kekuatan lain yang berani melakukan kontrol terhadap negara, bahkan rakyatpun tidak mampu menjadi locus of control (pusat kontrol) bagi kekuasaan negara yang tidak terbatas. Ketika ada aksi konfrontasi maupun koreksi terhadap pemerintah, tak jarang mereka harus berhadapan dengan moncong senjata yang dibawa oleh militer (Donnell \&. Schmitter, 1993:83).

Kekuasaan negara pada masa Orde Baru, menjadi sangat menghegemoni rakyat dan tidak ada kekuatan penyeimbang (balancing power). Singkatnya relasi negara dengan masyarakat bersifat dominasisubordinasi. Ketidaksejajaran inilah yang mengakibatkan konflik horizontal terus bertebaran diberbagai belahan Nusantara ini, yang pada akhirnya mencapai titik klimaksnya pada saat lengsernya rezim otoritarian tepatnya 21 Mei 1998. Potret buram historisitas bangsa Indonesia selama \pm 32 tahun ini menjadi pelajaran penting bagi tumbuh dan berkembangnya demokrasi di Indonesia.

Pasca reformasi atau sering disebut sebagai era transisi, relasi negaramasyarakat didasarkan pada sistem kesejajaran. Yang menjadi ciri yaitu terdapat ketegangan (tension) antara negara dan masyarakat. Oleh karena itu, hubungan keduanya tidak bisa dipetakan secara generalistis dan simplistis. Berbeda dengan sistem politik otoritarian, relasi negaramasyarakat jelas diidentifikasi sebagai hubungan yang timpang karena besarnya dominasi dan hegemoni negara terhadap masyarakat (Manan, 2005:206), sehingga rakyat tidak punya ruang kebebasan untuk mengaktualisasi dan mengapresiasikan gagasan-gagasan yang didasarkan pada nilai-nilai fundamental demokrasi (Masdar, 1999:80-81).

Dalam kesejajaran ini resistensi masyarakat terhadap negara memang relatif tinggi, namun dalam kasus-kasus tertentu negara juga tidak segan untuk merespon resistensi itu secara represif. Meskipun negara tampak tetap mampu melakukan 
Islam dan Demokrasi Pasca Orde Baru; Sembodo Ardi Widodo

tindakan represif terhadap masyarakat, secara umum dapat dikatakan bahwa posisi negara pada era transisi tetap melemah. Pelemahan ini disebabkan karena dua hal yaitu terjadinya fregmentasi di tubuh negara dan terbangunnya radikalisme massa terhadap negara. Pola relasi negaramasyarakat ini oleh Munafrizal Manan (2005:232) digambarkan sebagaiman Diagram I.

Dinamika relasi negara-masyarakat yang kompleks, merupakan cermin dari teori Anthony Giddens (2004) tentang dialectic of control yang muncul pada penguatan relatif dan pelemahan relatif pada negara dan masyarakat dan menempatkan posisi relasi negara-masyarakat yang relatif sejajar. Dalam posisi itu tidak terjadi negara yang sangat kuat atau masyarakat yang sangat kuat atau negara yang sangat lemah atau masyarakat yang sangat lemah. Inilah yang menjadi faktor peredam terjadinya kemungkinan pendominasian atau penghegemonian salah satu pihak terhadap pihak lain.

Jika era transisi ini negara mengalami fregmentasi, begitu pula halnya dengan masyarakat, sehingga peran mereka sebagai dialektika kendali terhadap negara terpolarisasi. Ini terjadi terutama pada

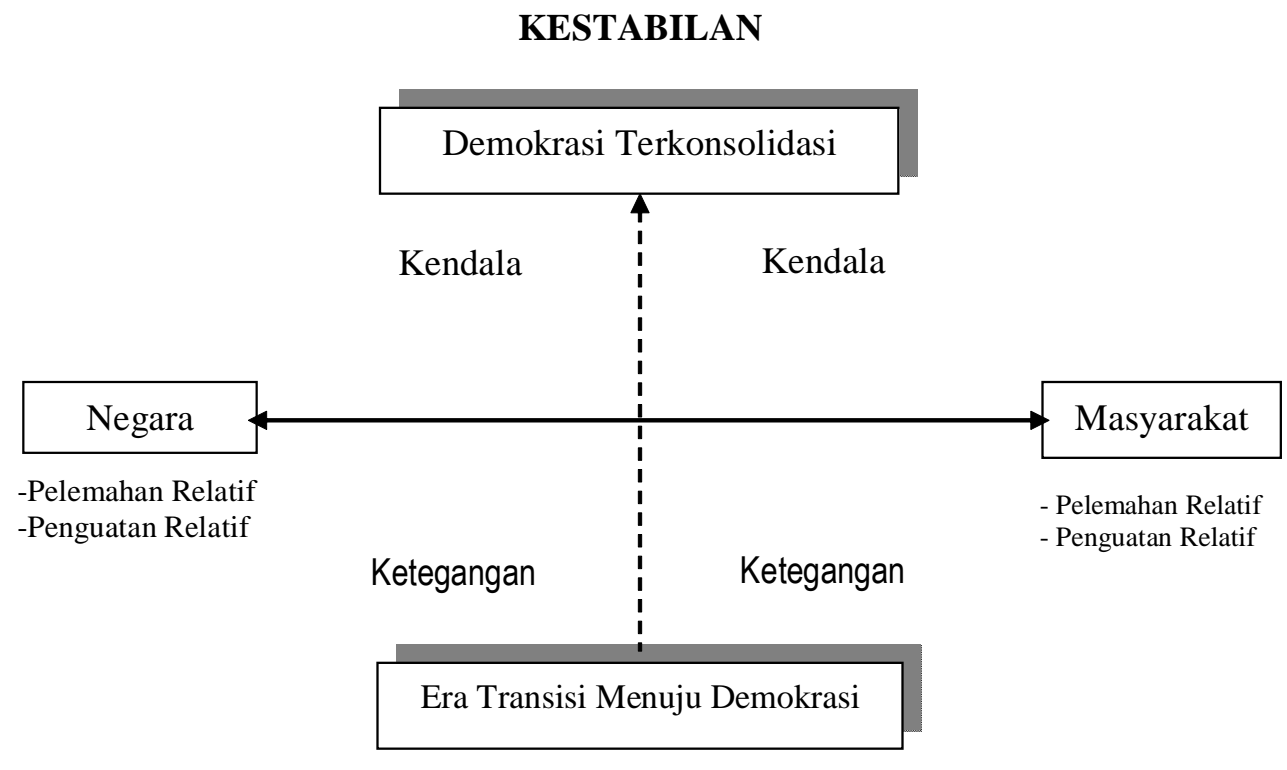

\section{KETIDAKPASTIAN}

DIAGRAM I :

Hubungan Negara-Masyarakat Pada Era Transisi Di Indonesia

Keterangan

$\longleftrightarrow$ : Garis posisi hubungan yang sejajar dan tegang

. . . . . : Garis kendala menuju demikrasi terkondosilidasi 
masyarakat akar rumput yang belum "melek politik" yang secara kuantitatif mendominasi di Indonesia. Pada sektor politik, demokrasi pun hanya dimaknai sebatas sistem politik tertentu, atau sebatas demokrasi prosedural yang tercermin dalam pemilu, ini merupakan pemaknaan yang sangat sempit. Menurut Georg Sorensen (2003:17) demokrasi bukan hanya sebuah sistem politik, tetapi juga sistem sosial ekonomi. Dengan demikian, peran negara menjadi sangat sentral dalam mewujudkan masyarakat melek politik melalui sistem multipartai dan pendidikan politik untuk mewujudkan konsolidasi demokrasi (consolidated democracy) (Diamond,2003:xx). Namun terus mengedepankan norma relasi kesejajaran antara negara dan masyarakat dan bukan dominasi ataupun hegemoni.

Sistem multipartai yang digunakan Indonesia telah mampu memberikan pencerahan terhadap perkembangan demokrasi, aspirasi rakyat semakin terakomodasi, pada tingkat ini peran partai politik diharapkan mampu menjadi struktur mediasi-struktur media bagi rakyat, sebagaii wujud kepedulian Parpol untuk melaksanakan pendidikan politik bagi rakyat. Pada aras lokal-pemeritah kabupaten/kotakebijakan desentralisasi dan otonomi daerah, telah memberikan secercah harapan bagi tumbuhkembangnya cita-cita bersama yang telah saya sebutkan di atas.

Terlebih pasca digulirkannya UU No. 22 tahun 1999 dan UU No. 25 tahun 1999 yang memberikan ruang yang lebih luas kepada daerah untuk mengakomodasi kedaulatan rakyak. Dengan demikian, civil society di aras lokal mempunyai peran yang strategis untuk membangun political society dan menciptakan masyarakat "melek politik". Hal ini menumbuhkan optimisme pada bangunan yang dialektis antara local state dan masyarakat akar rumput. Karena desentralisasi pada dasarnya adalah pendayagunaan local state dengan meningkatkan fleksibilitas proses-proses yang selama ini telah terbakukan untuk mengakomodasi tuntutan-tuntutan yang berkembang dalam masyarakat (Suwondo, 2004:313). Tak ayal, perjalanan penerapan UU Pemerintahan Daerah pun mencerminkan dinamika perubahan perpolitikan yang sangat berarti bagi pemerintah lokal.

\section{Budaya Politik}

Multipartai telah mendorong sistem demokrasi. Kebebasan berpendapat, berekspresi, kesederajatan merupakan agenda bersama yang terus diperjuangkan. Menurut Umaruddin Masdar (1999:83), sistem multipartai merupakan bagian mendasar untuk menyelenggarakan pemerintahan yang demokratis serta lembaga inilah yang mampu menampung aspirasi rakyat dan memberikan pendidikan politik bagi rakyat. Seperti halnya yang kita lihat bersama dalam kampanye partai politik menjelang pemilu sebagai representasi demokratisasi di Indonesia, terutama pada tahun 1999 dan 2004. Tak jarang, orator-orator handal yang ada di atas panggung untuk berkampanye, mengeluarkan janji-janji politik kepada rakyat. Senada dengan hal itu, presiden terpilih, Susilo Bambang Yudhoyono, juga melakukan hal yang sama, ia berjanji akan membenahi Indonesia dengan sistem "terapi kejut" program seratus hari yang menjadi andalannya dalam berkampanye.

Pendidikan murah, akses pelayanan kesehatan semakin mudah, bahan makanan juga akan semakin murah, namun apa yang terjadi?. Ternyata rakyat hanya dibuai dengan janji-janji politik yang sampai sekarang tidak mampu terealisir. Begitu pula elite politik kita yang sekarang sudah terpilih 
Islam dan Demokrasi Pasca Orde Baru; Sembodo Ardi Widodo

sebagai wakil rakyat-DPR, DPRD, MPRtelah melalaikan amanat yang diberikan kepadanya. Akhir-akhir ini, kita sering menyaksikan demonstrasi atau unjuk rasa yang dilakukan oleh mahasiswa, buruh, petani, dan padagang karena merespon berbagai persoalan yang muncul kepermukaan, akibat kebijakan yang tidak seimbang (missbalance). Namun, demonstrasi hanyalah sekedar demonstrasi, dan aspirasi hanya dipahami sebagai slogan kosong yang menjadi penghias dindingdinding ruang kantor yang megah yang mereka tempati.

Sebenarnya niat utama mereka dipilih sebagai wakil rakyat adalah untuk mewadahi aspirasi-suara rakyat. Meminjam istilah Sindhunata (200), "politik kita anti ketulusan" (Dalam Majalah Basis, No. 05-06, th. 2000). Partai politik hanya dijadikan sebagai kendaraan untuk merebut kekuasaan, setelah tampuk kepemimpinan diraihnya, mereka harus mengeruk keuntungan sebesar-besarnya, minimal modal mereka untuk berkampanye harus pulih kembali. Sialnya lagi, pola pikir komunalisme-yang dilatarbelakangi oleh partai politik-masih subur dalam tubuh elite politik kita. Yang penting adalah kelompok saya sudah terpenuhi segala kebutuhannya, sedangkan kelompok di luar saya itu persoalan lain. Inilah yang mendorong aktor-aktor politik melakukan korupsi, searus dengan itu, Transparancy International Corruption Perception Index (CPI) menyimpulkan hasil surveinya di Indonesia tentang korupsi, bahwa tingkat korupsi yang paling tinggi dilakukan oleh partai politik (Kompas, 01/ 03/2005). Wal hasil, partai politik kita memang sarat akan kepentingan individu, sialnya hal tersebut diperparah dengan masih membedakan antara kelompokA dan kelompok $\mathrm{B}$, terutama dalam membangun konsolidasi elite (Diamond, 2003:85).
Pada tahap ini, bangsa Indonesia sedang menjalani demokrasi prosedural yang tercermin dalam pemilu, baik pada tingkat lokal maupun pada tingkat nasional. Namun elite kita belum mencerminkan sikap dan prilaku demokrasi. Moralitas bangsa ini telah hancur tercabik-cabik oleh budaya korupsi, kolusi dan nepotisme, mementingkan diri sendiri dan ketidaktulusan menjadi wakil rakyat. Meskiupun sistem ini mampu merubah transfer kekuasaan yang sederhana diantara elite tradisional ke penyerahan kekuasaan kepada aktor-aktor politik baru (Donnell, 1993:315). Terus yang menjadi pertanyaan adalah kapan bangsa kita akan menjalankan demokratis subtansial atau konsolidasi demokrasi. Persoalan ini memang tidak mudah untuk dijawab, karena demokrasi membutuhkan waktu yang panjang, serta persiapan yang matang. Dan kita tidak bisa mengadopsi secara utuh proses demokratisasi di negaranegara tertentu seperti halnya demokratisasi di Eropa, karena setiap negara mempunyai proses dan karakteristik yang berbeda dan mempunyai korelasi yang sangat erat dengan bangunan kebudayaan suatu negara.

Kebudayaan sebagai modal sosial untuk membangun politik yang didasarkan pada norma-norma demokrasi, dan ketulusan untuk menjadi seorang pemimpin yang selalu siap mengakomodasi aspirasi rakyat. Karena bangsa ini sudah lama merasakan ketidaktulusan pada masa rezim Soeharto, rakyat selalu di bohongi untuk melanggengkan kekuasaannya (status quo). Budaya feodal yang menempatkan relasi antara negara dengan rakyat sebagai patron clien (hubungan tuan dan majikan) dengan 'penindasan struktural' yang dilakukan oleh negara agar rakyat tunduk dan patuh terhadap kebijakan-kebijakan yang dikeluarkan oleh negara, serta tidak ada 
UNISIA, Vol. XXX No. 65 September 2007

ruang kebebasan untuk berekspresi dan aktualisasi diri, harus kita dekonstruksi dengan nilai-nilai kesejajaran.

Budaya politik kita masih sebatas "politik tanding" yang terus menerus mengadu kekuatan antara kelompok yang satu dengan kelompok yang lain dan melakukan segala cara untuk merebut kekuasaan atau terus mencari celah-celah kelemahan, kecacatan, keburukan, kekurangan dan kesalahan pemimpin yang sudah terpilih, untuk kemudian menjatuhkannya, dan bukan membangunnya ke arah yang lebih baik. Lihat saja ketika masa kampanye partai politik, tak jarang mereka saling menghujat, mencemooh dan mencari titik kelemahan partai politik lain. Singkatnya, partai-partai tersebut terus menjadi kekuatan-kekuasan oposan bagi partai yang menang dalam pemilihan. Jelas bahwa oposisi terdiri dari kekuatan-kekuatan politik yang heterogen, dan bagaimanapun alamiahnya hal ini menciptakan persoalan dalam pencapaian kohesi kesatuan aksi. Terlepas dari aspek ideologisnya, heterogenitas ini mencerminkan ketegangan antara dua orientasi strategi yang pada prinsipnya komplementer, tetapi dalam prakteknya sulit dikombinasikan. Sialnya lagi, oposisi ini saling menarik keuntungan politik bagi dirinya, dan bukan bagi kepentingan oposisi keseluruhan.

Konflik ini terus mencuat ketika pelaksanaan PILKADA (Pemilihan Kepada Daerah) yang diselenggarakan di seluruh Kabupaten kota, sebagai realisasi UU Otonomi Daerah. Seperti yang terjadi di Depok, Jember, Madura, Gresik, Banyuwangi, Situbondo, Halmahera Barat dan lainlain. Seharusnya PILKADA dapat dijadikan sebagai media pendidikan politik bagi masyarakat akar rumput dengan mengedepankan nilai-nilai demokrasi, bukan dijadikan sebagai ajang perebutan kekuasaan yang jauh dari nilai-nilai proses pendidikan politik bagi rakyat. Inilah potret buram politik kita sampai sekarang.

\section{Konsolidasi Demokrasi Indonesia}

Terdapat tiga prasyarat penting yang harus dipenuhi oleh negara yang baru jika mereka ingin terkonsolidasi: penguatan demokrasi, pelembagaan politik, dan kinerja rezim. Penguatan membuat struktur-struktur formal demokrasi menjadi lebih liberal, memliki akuntabilitas, representatif dan terjangkau. Kemajuan dan kepatuhan hukum yang lebih besar adalah sangat penting (Diamond,2003:93). Tiga pilar tersebut secara umum bisa dikatakan masih lemah di Indonesia, terutama jika kita melihat penegakan hukum di Indonesia. Upaya untuk bergerak secara sinergis tiga elemen tersebut dapat dijadikan sebagai solusi alternatif bagi terbentuknya sebuah tatanan demokrasi.

Hal yang tidak kalah penting adalah, relasi negara-masyarakat harus berjalan secara sinergis yang termasuk di dalamnya civil society dan political society. Sinergitas ini merupakan indikator bahwa relasi tersebut tidak didasarkan pada unsur dominasisubornasi, namun pada karakter equality (kesejajaran). Meskipun pada aras lokal, kualitas pendidikan politik masyarakat tidak bisa dijadikan sebagai tiang penyangga terciptanya konsolidasi demokrasi, namun setidaknya dengan sinergitas tiga elemen di atas, paling tidak kita mempunyai secercah harapan terhadap bangunan demokrasi di Indonesia.

Yang lebih penting disini adalah konsolidasi tidak hanya sekedar komitmen pada demokrasi secara abstrak, bahwa demokrasi "pada prinsipnya" adalah bentuk terbaik pemerintahan. Agar demokrasi 
Islam dan Demokrasi Pasca Orde Baru; Sembodo Ardi Widodo

terkonsolidasi, para elite, organisasi dan massa, sepenuhnya harus percaya bahwa sistem politik yang mereka miliki di negara mereka ini banyak dipatuhi dan dipertahankan. Legitimasi yang kokoh ini meliputi komitmen normatif dan prilaku bersama pada aturan dan praktik-praktik khusus dari sistem konstitusional negara tersebut atau disebut dengan "loyalitas" demokrasi.

Sebagaimana yang saya uraian di atas, bahwa masyarakat setidaknya dapat berfungsi sebagai dialectic of control terhadap kekuasaan negara yang didudukkan secara seimbang untuk membangun kultur yang demokratis. Kesepakatan bersama juga ditempuh melalui representasi rakyat yang terjelma pada lembaga negara yang memiliki otoritas untuk mewakili masyarakat. Prinsip imperatif normatif tersebut bila dicerminkan pada kondisi obyektif era transisi di Indonesia menunjukkan bahwa usaha menuju demokrasi terkonsolidasi bukanlah hal yang mudah (Manan, 2005:218). Pada era transisi ini civil soviety dan political society mengidap penyakit internal-seperti yang saya jelaskan di atas-yang dapat merintangi jalannya demokrasi terkon-solidasi.

Penguatan ditingkatan masyarakat yang tercermin dalam resisten dan kontrol terhadap negara, ternyata juga masih dihinggapi oleh konflik horizontal, dimana mereka terus berhadapan dengan kekuatan militer seperti yang terjadi pada kasus Saluran Udara Tegangan Ekstra Tinggi (SUTET) PLN-yang terjadi di dua daerah Bandung dan Yogyakarta, kasus Bantuan Langsung Tunai dari BBM yang menelan korban, demonstrasi yang seringkali disertai dengan aksi kekerasan para demonstran, seperti yang terjadi di Surabaya 16 Januari 2006, dan lain sebagainya. Rupanya, masyarakat kita sedang mengidap penyakit patologi sosial yang akut dan harus segera mendapatkan terapi agar demokrasi terkonsolidasi yang menjadi agenda kita bersama cepat terwujud.

Optimisme ini tentu harus dibarengi dengan usaha yang serius oleh berbagai elemen sebagai penyangga demokrasi. Apabila tidak, mustahil cita-cita bersama itu akan terealisir. Memang membangun iklim demokrasi tidaklah semudah membalik telapak tangan, tetapi membutuhkan proses panjang dan harus melintasi jalan yang terjal yang penuh dengan rintangan. Bangsa Indonesia tidak boleh psimis dengan kondisi yang ada sekarang, dan ditambah dengan problem sosial yang sangat komplek. Niatan bersama untuk membangun demokrasi terkonsolidasi merupakan modal sosial yang tidak ternilai harganya

\section{Penutup}

Secara umum, sangat disadari bahwa aktor-aktor politik pada skala nasional maupun lokal, sangat dibutuhkan keberadaan fungsi subtansinya dalam mewujudkan perubahan terhadap situasi dan kondisi yang sekarang dihadapi oleh bangsa Indonesia. Pada tingkat masyarakat, resistensi terhadap negara dengan mengedepankan fungsi kontrol (dialectic of control) dan sikap kritis terhadap persoalan yang ada, merupakan tujuan bersama dalam membangun demokrasi terkonsolidasi. Karena itulah, hadirnya konsolidasi demokrasi memang merupakan sebuah tatanan yang sangat ideal dan menjadi tujuan kita bersama.

Melihat hal itu, negara dan masyarakat, serta agama dengan komitmen normatifnya telah mempunyai peran yang sangat strategis dalam mewujudkan tatanan tersebut. Meskipun ketiganya masih tetap 
UNISIA, Vol. XXX No. 65 September 2007

mempunyai beberapa titik kelemahan. Tiga kekuatan sosial tersebut, dalam konteks sejarah Indonesia, telah menjadi modal sosial (social capital) sebagai kunci keberhasilan untuk menciptakan sistem pemerintahan yang demokratis. Tentunya dengan catatan bahwa ketiganya berjalan atas dasar kesejajaran bukan atas dasar dominasi dan hegemoni.

\section{Daftar Pustaka}

A. Dahl, Robert, 1989, Democracy and lts Critics, New Haven: Yale University Press.

Al-Mawardi, Abu Hasan Ali bin Muhammad bin Habib al-Bashri, Tanpa tahun, alAhkam as-Sultaniyyah, Beirut; Dar alFikr.

Al-Qur'an dan Tejemahnya, Madinah: Mujamma' al-Malik al-Fahd, $1418 \mathrm{H}$..

Berger, Peter, L., 1973, The Social Reality of Religion, Harmonsdworth: Penguin Books..

Budiman, Arief dan Törnquist, Olle 2001, Aktor Demokrasi; Catatan Tentang Gerakan Perlawanan di Indonesia, Yogyakarta, ISAI,

Culla, Adi Surya, 1999, Patah Tumbuh Hilang Berganti; Sketsa Pergolakan Mahasiswa dalam Politik dan Sejarah Indonesia (1908-1998), Jakarta: Rajawali Press.

Diamond, Larry, 2003, Developing Democracy; Toward Consolidation, alih bahasa Tim IRE Yogyakarta, Yogyakarta, IRE Press.
Ecip, Sinansari, 1998, Kronologi Situasi Penggulingan Soeharto, Bandung; Mizan,.

F. Thompson, Dennis, 2000, Political Ethics and Public Office, Yayasan Obor Indonesia (terj), Jakarta; Yayasan Obor Indonesia.

— 1989 , Abangan, Santri, Priyayi Dalam Masyarakat Jawa, Jakarta, Pustaka Jaya.

Giddens, Anthony, 2004, The Constitution Of Society; The Outline of The Theory of Structuration, alih bahasa Adi Loka Sujono, Malang, Pedati.

Haikal, Muhammad Husein, tth, alHukumah al-Islamiyyah, Darul m'arif: Kairo,.

Haramain, A. Malik., 2004, Gus Dur, Militer, dan Politik, Yogyakarta; LkiS,.

Hefner, Robert William, 2001, Civil Islam dan Demokratisasi di Indonesia, Ahmad Baso (terj), Yogyakarta; LkiS,.

HR, Ridwan, 2002, Hukum Administrasi Negara, Yogyakarta; UII Press Indonesia,.

Kleden, Ignas, 2000, Sentimen Daerah dan Kabinet Baru, Tempo, 24 September.

Ma'arif, Ahmad Syafi'i, 1999, Islam dan Politik: Upaya Membingkai Peradaban, Imron Nasri (ed), Cirebon; Pustaka Dinamika,.

Manan, Munafrizal, 2005, Gerakan Rakyat Melawan Elite, Yogyakarta, Resist Book. 
Islam dan Demokrasi Pasca Orde Baru; Sembodo Ardi Widodo

Mangunkusumo, Daliso, 1999, Tradisi Kekerasan Politik di Indonesia, Yogyakarta; Lembaga Kajian Prospek Yogyakarta,.

Marijan, Kacung, 1992, “NU's Response to the New Order's Political Development", The Indonesiaa Quarterly Vol.xx, No. I $1^{\text {st }}$ Quarter, Indonesia.

Masdar, Umaruddin dkk, 1999, Mengasah Naluri Publik Memahami Nalar Politik, Yogyakarta, LKiS

Muhammadiyah Movement in Indonesia, PP Muhammadiyah, Yogyakarta, Indonesia, t.th.

Mulkhan, Abdul M., 1992, Runtuhnya Mitos Politik Santri, Yogyakarta: Sipress,.

Nakamura, Mitsuo, 1980, The Reformist Ideology of Muhammadiyah in Indonesia; The Making of a Nation, (Fox,J,J., ed), Australian National University, Australia,.

Donnell, Guillermo dkk, 1993, Transisi Menuju Demokrasi; Kasus Amirika Latin, Jakarta, LP3ES , dan C. Schmitter, Philippe, 1993, Transisi Menuju Demokrasi; Rangkaian Kemungkinan dan Ketidakpastian, Jakarta, LP3ES

Piötr Sztompka, 2005, Sosiologi Perubahan Sosial, Jakarta, Prenada

Raharjo, M. Dawam., 1996, Ensiklopedi alQuran: Tafsir Sosial Berdasarkan Konsep-Konsep Kunci, Jakarta: Paramadina,.
Rais, Amien, 1998, Membangun Politik Adiluhung; Membumikan Tauhid Sosial Menegakkan Amar Ma'ruf Nahi Munkar, Bandung; Zaman Wacana Mulia,.

Shari'ati, Ali, 1996, Tugas Cendekiawan Muslim, (terj) Amin Rais, Jakarta; Raja Grafindo Persada,.

Soehino, 1999, "Masa Depan Hukum dan Demokrasi Indonesia Menggagas Paradigma Hukum yang Berdaulat," dalam M.AS Hikam dkk., Wacana Politik Hukum dan Demokrasi Indonesia, Yogyakarta; Pustaka Pelajar,.

Sorensen, Georg 2003, Demokrasi dan Demokratisasi; Proses dan Prospek Dalam Sebuah Dunia yang Sedang Berubah, alih bahasa I Made Krisna Yogyakarta, Pustaka Pelajar

Stepan, Al fred, 1996, Militer dan Demokrasi; Pengalaman Brazil dan Beberapa Negara Lain, alih bahasa Bambang Cipto, Jakarta: Pustaka Utama Grafiti

Suwondo, Ketut dkk, 2004, Yang Pusat dan Yang Lokal; Antara Dominasi, Resistensi dan Akomodasi Politik di Tingkat Lokal, Yogyakarta, Pustaka Pelajar.

Taimiyah, Ibnu., 1963, Majmu' Fatawa ashShayh al-Islam Ahmad Ibnu Taymiyyah, Jilid 28, Riyadh: Matabi' a-Riyadh,. , Tanpa Tahun, as-Siyasah ashShar'iyyah, edisi Dar al-Shaib. 
UNISIA, Vol. XXX No. 65 September 2007

U.S. Department of State, 1997, Country Wahid, Abdurrahman, Tanpa Tahun, Reports on Human Right Practices for 1996, Washington DC: Government Printing Office. "Sosialisasi Nilai-nilai Demokrasi dan Transformasi Sosial”, Artikel, tidak diterbitkan.

$\square \square \square$ 